\title{
The Homogenization of two Different Natural Ecosystems by Conversion to Pasture in the Southern Espinhaço, Brazil
}

\author{
Natália Viveiros Salomão ${ }^{1}$ (1) \\ Geraldo Wilson Fernandes ${ }^{2}$ \\ Rafaella Silva Pereira ${ }^{1}$ \\ Danielle Piuzana Mucida ${ }^{3}$ (1) \\ Leovandes Soares da Silva ${ }^{1}$ (D) \\ Anne Priscia Dias Gonzaga ${ }^{3}$ \\ Evandro Luiz Mendonça Machado ${ }^{1}$
}

\begin{abstract}
Fragmentation of natural areas alters the natural landscape, removing native vegetation and creating an anthropic matrix. In order to better understand the consequences of grazing in areas of campo rupestre and forest, the present study aimed to analyze changes in the vegetation of Cerrado and Atlantic Forest, in the Southern Espinhaço, between 1979 and 2015. The vegetation of the study area was identified as arboreal (forest), or herbaceous or shrubby (campo rupestre) by visual classification of a mosaic of aerial photographs from 1979 and the supervised classification of land use from a Landsat 8 image from 2015. Differences in vegetation were analyzed using a transition matrix based on the "Markov model", which indicated conversions of vegetation classes due to the misuse of land, mainly as pasture. The results indicate the conversion of arboreal vegetation area into areas of exotic herbaceous vegetation, and stability in the area of shrubby vegetation.
\end{abstract}

Keywords: Arboreal, herbaceous, landscape ecology, shrubby.

\section{INTRODUCTION}

One of the main causes of accelerated deforestation has been livestock activity, with the direct consequence of the conversion of native areas into pastures (Pendril et al., 2019). Fragmentation of the transition region between the vegetation of Atlantic Forest and Cerrado is the result of constant degradation of their natural ecosystems due to the misuse of land for agriculture and, mainly, for pasture (Salomão et al., 2018). This degradation alters more than just the biodiversity of the region because the region also encompasses an extensive drainage network, and thus serves an important role in regional nutrient recycling (Mingoti et al., 2016).

The removal of native forest alters the soil because the absence of vegetation can increase temperatures, cause erosion and modify the water balance (Mao et al., 2018). The creation of isolated fragments is due to the replacement of natural vegetation with different ecosystems, such as pastures and agricultural fields, thus immersing fragments in an anthropic matrix (Santos et al., 2019). Such landscape mosaics of tropical vegetation are subject to constant perturbation (Staal et al., 2018).

According to Nóbrega et al. (2017), the conversion of tropical savannas to pasture can also cause a regional decrease in mean monthly precipitation. Furthermore, even if there is no resulting change in mean precipitation, there will certainly be an increased frequency of the dry season. Changes in climate patterns due to pastures can make areas of vegetation transition increasingly susceptible to invasion by exotic plants (Garcia \& Ballester, 2016).

Vegetation transformation in the municipality of Conceição do Mato Dentro, caused structural evolution of the communities of campo rupestre (Cerrado) and dense ombrophilous forest (Atlantic Forest), mainly due to the creation of pastures. This, in turn, has led to more and more changes to the optimal

${ }^{1}$ Universidade Federal dos Vales do jequitinhonha e Mucuri, Departamento de Engenharia Florestal, Diamantina, MG, Brasil.

${ }^{2}$ Universidade Federal de Minas Gerais, Departamento de Biologia Geral, Belo Horizonte, MG, Brasil.

${ }^{3}$ Universidade Federal dos Vales do Jequitinhonha e Mucuri, Faculdade Interdisciplinar em Humanidades, Diamantina, MG, Brasil. 
conditions of survival and reproduction for native species, and an increase in invasive species adapted to the new conditions (Salomão et al., 2019). In addition, this type of anthropism can result in other environmental impacts in the area, such as annual burning since fire is still used as a tool to expand agricultural areas (Resende et al., 2017).

To support this transformation in the Atlantic ForestCerrado transition, $35 \%$ of the open areas of Cerrado in Brazil had already been replaced by pastures by 2013 (see project TerraClass Cerrado - MMA, 2015). The concern with conserving the area is with the loss of biodiversity due to the alteration of the landscape by fragmentation, since this affects the biotic environment in the landscape and, consequently, the distribution of species (Resende et al., 2017). In this way, ecological conservation depends on native vegetation cover and how it is spatially distributed. Campo rupestre in the Southern Espinhaço have been subjected to degradation due to a variety of factors, but mainly the lack of ecological knowledge and poor management, which has resulted in the introduction of invasive exotic species (Fernandes, 2016).

Despite the high biodiversity and endemism of the study region, it has experienced intense habitat loss due to fragmentation caused by unregulated land use. Within this context, there is great concern about the campo rupestre, as it currently has one of the highest rates of land use conversion in Brazil (Garcia \& Ballester, 2016). Furthermore, there have been no scientific studies in the area to inform local public policies regarding sustainable management of natural resources and restoration of impacted areas, and so monitoring of land use and occupation in the region is essential.

In view of the present concern, this study aimed to quantify conversion of forest and campo rupestre due to changes in land use and occupation by analyzing vegetation classifications from satellite images and assessing the effects associated with these losses.

\section{MATERIALS AND METHODS}

\subsection{Description of the study area}

The studied area is located within the transition between the Cerrado and Atlantic Forest biomes in the municipality of Conceição do Mato Dentro, state of Minas Gerais, Brazil. The area encompasses 12,359 hectares and, according to the classification of Köppen - Geiger (1929), the climate of the region is tropical altitude, which is represented by elevations above $500 \mathrm{~m}$, mild temperatures between $18^{\circ} \mathrm{C}$ and $26^{\circ} \mathrm{C}$, a thermal amplitude between $7{ }^{\circ} \mathrm{C}$ and $9{ }^{\circ} \mathrm{C}$ and elevations varying between 679 and 1472 meters a.s.l.
In the region of transition, areas of dense ombrophilous forest at higher elevations are composed of arboreal vegetation, while those of campo rupestre are composed of herbaceous vegetation dominated mainly by native and exotic grasses and a composite shrub vegetation of scattered twisted trees and shrubs. Areas of dense ombrophilous forest and campo rupestre in Conceição do Mato Dentro have been converted to pasture by the introduction of invasive exotic grasses such as Braquiaria decumbes (Salomão et al., 2018). This fact is worrisome since the region has a history of accentuated fragmentation, which when added to the conversion of dense ombrophilous forest and campo rupestre to pasture, further favors the loss of biodiversity (Salomão et al., 2019).

\subsection{Image processing and classification}

To analyzing the transition probability for areas according to vegetation class, vegetation coverage for the years 1979 and 2015 was mapped. The year 1979 was the first year for remote sensing of the non-fragmented area. The thematic classes used were establish from field work carried out in the study area, which aimed to capture the type of vegetation, soil conservation status and anthropic use.

The arboreal vegetation class was comprised of dense ombrophilous forest at elevation areas that had not been anthropized by pasture and agriculture. The campo rupestre was classified as shrubby, being composed of medium-sized vegetation in areas of higher elevations with the presence of agricultural crops, and herbaceous, being covered by creeping native and exotic vegetation and characterized by the occurrence of Brachiaria decumbens in pasture areas. The vegetation classification was first performed visually in the field in July 2015.

\subsubsection{Mosaic of aerial photographs (flights of December, 1979)}

A mosaic is a set of aerial photographs registered and united by adjustments and overlaps (Cunha et al., 2006). The mosaic of the present study (Fig.1) was created from 17 aerial photographs of the study area, which were located in a photograph from the municipality of Presidente Kubitschek (sheet 2460). The photos were provided by Companhia de Pesquisa de Recursos Minerais (CPRM) and transferred to Casa da Glória do Instituto de Geociências da Universidade Federal de Minas Gerais (IGC-UFMG). After georeferencing, the photographs were combined in a mosaic using the mosaiking tool of Envi 4.5 software. 


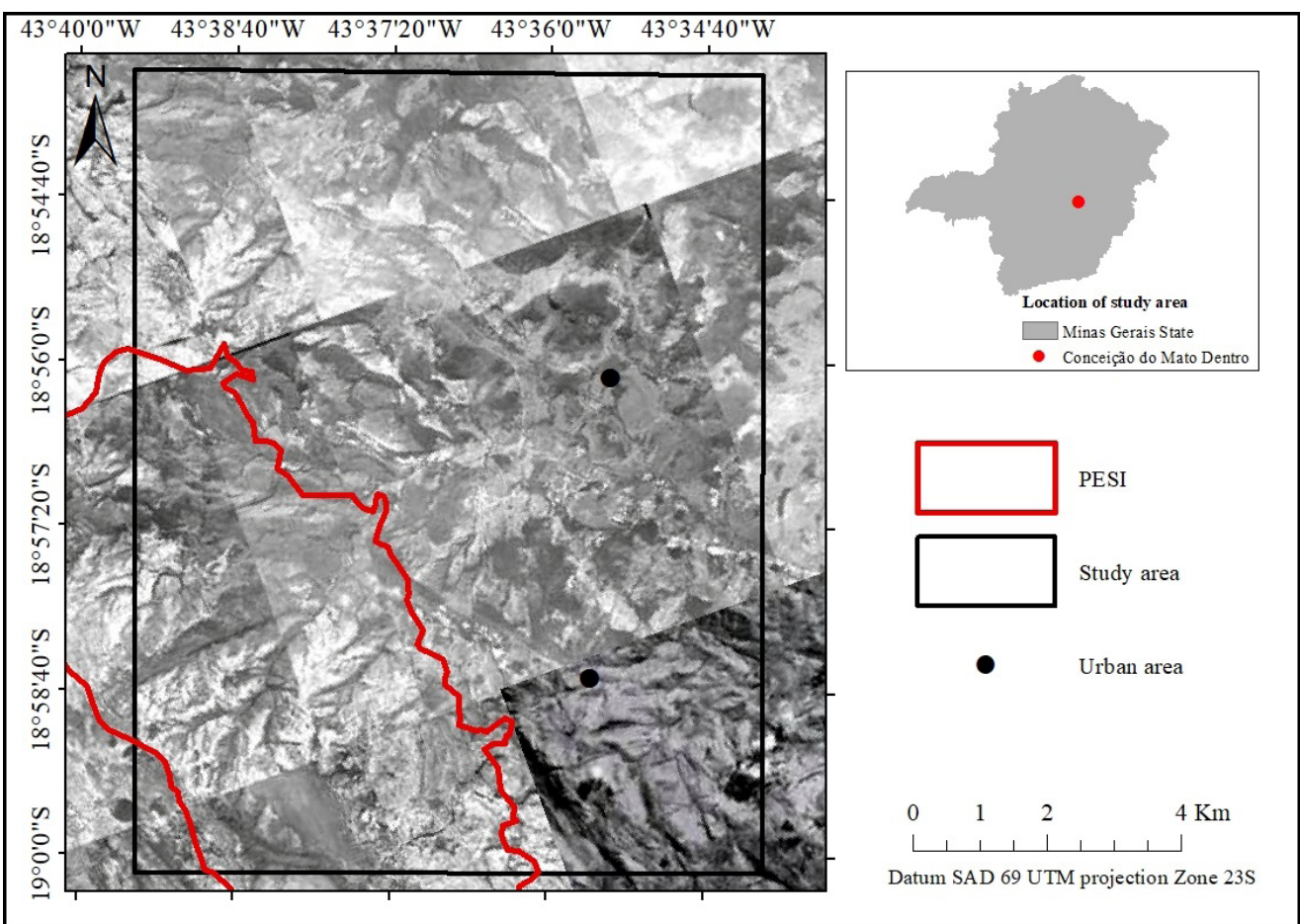

Figure 1. Mosaic of aerial photographs of the study area including part of Parque Estadual Serra do Intendente (PESI).

The visual classification of the vegetation of the mosaic was based on the key of vegetation for fragments proposed by Panizza \& Fonseca (2000) and resulted in the three classes of vegetation: arboreal, shrubby and, herbaceous. The parameters evaluated were color intensity (tonality), saturation, texture and appearance. According to the interpretation key for panchromatic images (black and white) proposed by Messias (2012), areas colored white and represented by smooth texture and irregular shape are classified as "bare rock" (Table 1).

Table 1. Visual classification of the vegetation of the study area

\begin{tabular}{|c|c|c|c|c|}
\hline Classes & Tonality & Saturation & Texture & Appearance (irregular) \\
\hline Arboreal & Very dark gray & High & Fine & \\
\hline Shrubby & Dark gray & Medium & Fine & \\
\hline Herbaceous & Light gray & Low & Fine & \\
\hline Bare rock & Very light gray & - & - & \\
\hline
\end{tabular}


To analyze the vegetation for 2015 , a Landsat 8 satellite image from 18 July, 2015, was used to produce a map of land use and occupation. All satellite images show systematic distortions during the acquisition process, and so geometric correction (registration) was necessary (Espirito-Santo \& Shimabukuro, 2005). To register the image, the 2010 Geocover image of the state of Minas Gerais was used as a spatial reference. This process was done with corresponding control points of the two images using the registration tool of Envi 4.5 software.

\subsubsection{Supervised classification of Landsat 8}

According to Rudorff et al. (2007), supervised classification of images is the most widely used method for quantitative analysis of data and is based on the use of algorithms to determine the pixels that represent values for a certain class. This method requires prior knowledge of the number of classes of land use and coverage contained in the image. Supervised classification for land use and occupation of the study area
(Fig. 2) was developed based on previous knowledge of sampling points obtained during fieldwork conducted in July 2015, which determined a class of arboreal vegetation for areas of forest, and a class of shrubby and, herbaceous vegetation for areas of campo rupestre. The herbaceous vegetation comprises pasture areas and may be exotic or native.

The points sampled in the field were inserted and analyzed within the accuracy indexes global accuracy and Kappa described by Bolfe et al. (2004); according to the author, the accuracy values for the indexes should be above $85 \%$. Kappa tests are used to measure the accuracy of image classifications because the test is able to account for all elements in a confusion matrix (Hua 2017). These values were obtained using the software Envi 4.5 from the confusion matrix generated with the post classification option for the comparison between the regions of interest of the classified image and the classification observed in the field. The accuracy (global 94\%, Kappa 86\%), indicated that the classification was satisfactory and better than would be obtained from a random classification.

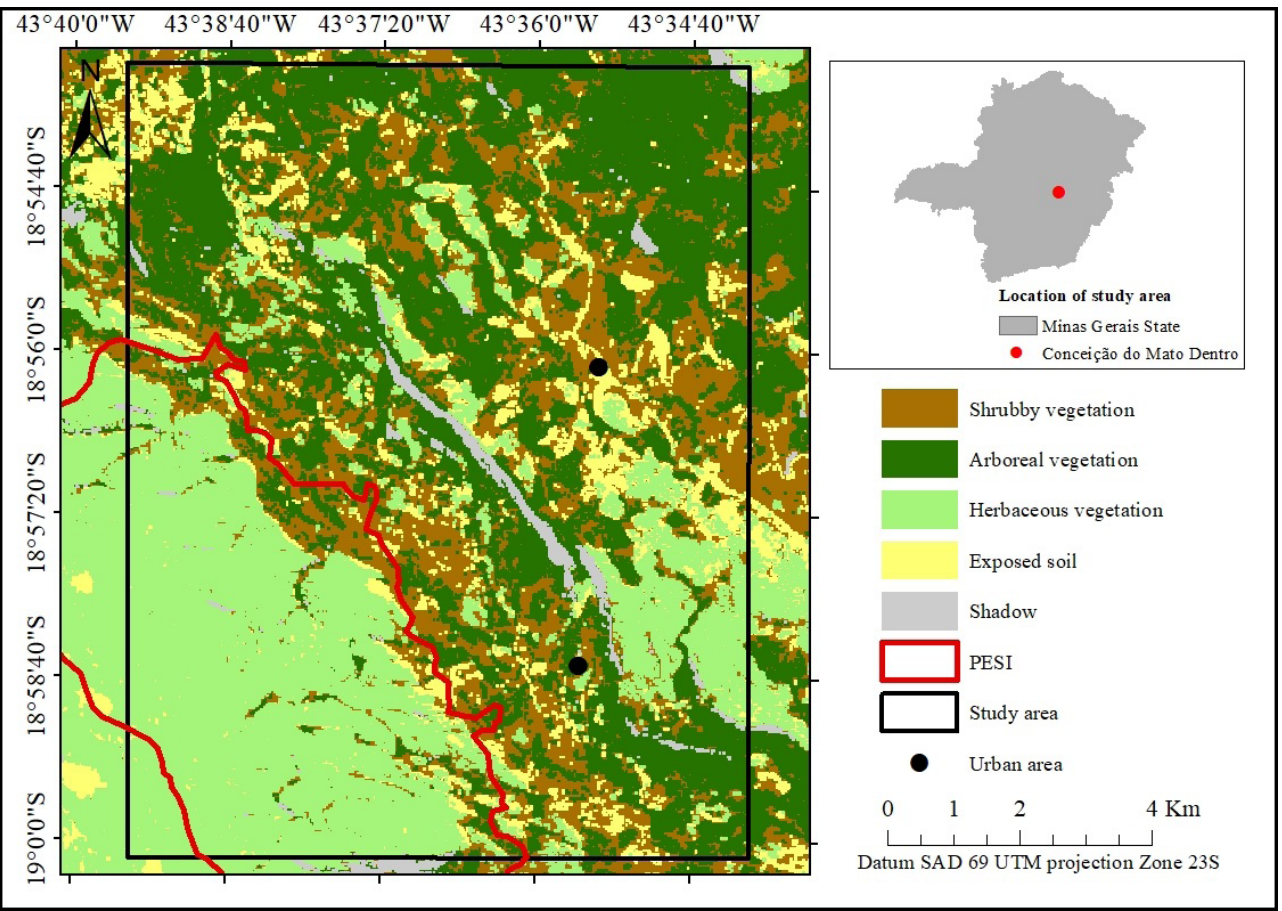

Figure 2. Land use and occupation in the study area for 2015, which includes part of Parque Estadual Serra do Intendente (PESI) and the urban area.

\section{DETECTION OF CHANGE AND THE TRANSITION MATRIX}

The transition matrix permitted the analysis of the processes behind the probable patterns of vegetation change through pixel-to-pixel comparison of losses and gains of the area of vegetation classes (Romero-Ruiz et al., 2012) as a function of land use and occupation differences between the mosaic of aerial photographs (1979) and the satellite image (2015). Areas of the vegetation classes were calculated using the software Envi 4.5.

The Markov Model consists of making a transition matrix whose purpose is to describe changes in populations or 
communities (Gotteli, 2009). According to Nappo (2005), the only requirement of this model is that populations can be separated into groups of states and that there is the possibility of transition from one state to another over a given time.

Changes in land use and coverage, simulated from Markov Chains, are based on probability theories and given by the equation 1 (Ruhoff et al., 2010):

II $t^{+1)}=p n$ II $t$

Where $\mathrm{II}^{(\mathrm{t})}$ corresponds to the state of the system at time $t, t+1$ corresponds to the state of the system after that instant $(t)$ and $P n$ are the possible states that are represented in matrices of transition possibilities. These transition matrices represent the possibility of a given state $i$ remaining the same or changing to state $j$ during the time instant $t \geq(t+1)$.

The transition matrix for three classes (arboreal, shrubby and herbaceous), showed the proportion of the total landscape area lost, represented by the rows (1979), and the total area gained, represented by the columns (2015). The notation Aij (where $i \neq j$ ) indicates the proportion of the landscape that went through a transition from class $i$ to class $j$ between the years 1979 and 2015; the main diagonal elements, with the notation $\mathrm{Ajj}$, indicate the proportion of classes that exhibited persistence of class $j$; the proportion of the Ai+ landscape that is occupied by class i in 1979 (Coelho et al., 2014), is given by equation 2 :

$\mathrm{n}$

$$
\begin{gathered}
\mathrm{Ai}+=\sum \mathrm{Aij} \\
\mathrm{i}=1
\end{gathered}
$$

where: $n$ is the total number of classes.
The proportion of $\mathrm{A}+\mathrm{j}$ landscape that is occupied by class $\mathrm{j}$ in 2015 , is given by equation 3 :

$$
\begin{gathered}
\mathrm{n} \\
\mathrm{A}+\mathrm{j}=\sum \mathrm{Aij} \\
\mathrm{i}=1
\end{gathered}
$$

Finally, the probabilities of each state of the matrix were arranged in a vector $\pi$ called the State Probability Vector. The classes that had a probability of change below $3 \%$ were considered insignificant and, therefore, were not analyzed.

\subsection{Edge metrics}

To calculate the edge effect, we used the landscape metrics of total edge (TE) and mean of area-perimeter ratio (PARA MN) by vegetation class of 1979 and 2015 using the software Fragstats 4.2. Classes that had lower mean area-perimeter ratio and higher total edge had higher edge effect. An edge of 100 meters was considered for the calculation of the metrics.

\section{RESULTS}

\subsection{Change in areas of classes from 1979 to 2015}

From 1975 to 2015 the area of arboreal vegetation suffered a retraction, as indicated by the negative value, whereas the areas of the shrubby and herbaceous classes underwent expansions, as represented by positive values (Table 2).

Table 2. Areas for vegetation classes in the study area for 1979 and 2015.

\begin{tabular}{ccccccccc}
\multicolumn{8}{c}{ Vegetation Classes } \\
\hline Area(ha) & Arboreal & Shrubby & Herbaceous & Exposed rock & Exposed soil & Total area & Vegetated area \\
\hline 1979 & 6,573 & 3,033 & 505 & 2,248 & - & 12,359 & 10,111 \\
2015 & 4,045 & 3,932 & 3,259 & - & 1,123 & 12,359 & 11,326 \\
$1979-2015$ & $-2,528$ & +899 & $+2,754$ & $-2,248$ & $+1,123$ & 4,776 & $+1,125$ \\
\hline
\end{tabular}

Table 3. Matrix of transition probabilities among vegetation classes of the study area for the years 1979 and 2015.

\begin{tabular}{ccccccc} 
& \multicolumn{3}{c}{2015} & & & \\
\hline & & Arboreal & Shrubby & Herbaceous & Total \\
\hline & Arboreal & 0.73 & 0.03 & 0.24 & 1 \\
& Shrubby & 0.03 & 0.77 & 0.20 & 1 \\
& Herbaceous & 0.20 & 0.17 & 0.63 & 1 \\
& & & 0.96 & 0.97 & 1.07 & 3
\end{tabular}

The values of Table 3 were arranged in vector $\pi$ (stwate probability vector): 


$$
\pi=\left(\begin{array}{llll}
0.73 & 0.03 & 0.24 \\
0.03 & 0.77 & 0.20 \\
0.20 & 0.17 & 0.63
\end{array}\right)
$$

\subsection{Border effect}

For 1979, the mean perimeter-area ratio varied little among classes, therefore only total edge was considered. For 2015, the mean perimeter-area ratio (PARA_MN) also varied little among classes, and so only total edge was also considered. Because arboreal vegetation had the highest total edge it had the greatest edge effect, while herbaceous vegetation had the lowest total edge and thus the least edge effect (Table 4).

Table 4. Mean area-perimeter ratio (PARA_MN) and total edge (TE) for the vegetation classes of the study area for the years 1979 and 2015.

\begin{tabular}{ccccc}
\multirow{2}{*}{ CLASS } & \multicolumn{2}{c}{ PARA_MN } & \multicolumn{2}{c}{ TE } \\
\cline { 2 - 5 } & $\mathbf{1 9 7 9}$ & $\mathbf{2 0 1 5}$ & $\mathbf{1 9 7 9}$ & $\mathbf{2 0 1 5}$ \\
\hline $\begin{array}{c}\text { Arboreal } \\
\text { vegetation }\end{array}$ & $1116: 0577$ & $1049: 4862$ & 3,929 & 781,975 \\
$\begin{array}{c}\text { Shrubby } \\
\text { vegetation }\end{array}$ & $1108: 6412$ & $1060: 5243$ & 1,862 & 140,094 \\
$\begin{array}{c}\text { Herbaceous } \\
\text { vegetation }\end{array}$ & $1030: 6903$ & $1035: 4481$ & 180 & 10,998 \\
\hline
\end{tabular}

\section{DISCUSSION}

\subsection{Transitions in the dense ombrophilous forest}

The transition of areas from 1979 to 2015 revealed an accelerated reduction of vegetation cover with the substitution of native vegetation by pasture and agriculture. During the period from 1979 to 2015, the arboreal class experienced the greatest reduction in area with a loss of 2,528 hectares (Table 2) in the study region.

The gross loss of area for the arboreal class was due to the ease of deforestation in flat areas for the establishment of pasture and agriculture, which confirms that accessibility is one of the main factors behind deforestation (Pleniz 2016). According to Filho \& Moura (2016), declivity is one of the most widely considered parameters in methodologies for land use suitability classification in Brazil and is directly related to livestock and agricultural practices, which explains the conservation of the humid ombrophilous forest in the steepest areas of the study area.

Extensive areas of native forest undergoing rapid changes result in a "fish bone" type of pattern (Maurano et al., 2019), which may have favored changes in the composition of arboreal vegetation in flat areas mainly due to agriculture and livestock. This pattern has a significant effect on ecological relationships since the isolation of an area reduces gene flow, promoting low genetic diversity, and affects the local microclimate, the hydrological cycle, maintenance of natural resources, the protection of slopes and oxygen production and CO2 capture, among other effects (Dantas et al., 2017).

A reduction in the area-perimeter ratio and an increase in total edge of the arboreal class (Table 4) were observed from 1975 to 2015 , which caused an effective increase in the edge effect for those areas. The size of the edge area of fragments is directly related to the surrounding environment, such that the type of matrix near fragments can make the edge effect more or less intense. (Costa et al., 2019).

Fragments with lower area/perimeter ratios, due to greater edge effect, are subject to changes to the microclimate within fragments, such as increased internal temperature and occupation by invasive species. (Fernandes \& Fernades 2017). Thus, for this study, we can conclude that the edge effect for the arboreal class from 1979 to 2015 was certainly a result of forest fragmentation for the establishment of pasture and agriculture, and is related to the potential conversion of $24 \%$ of its area into the herbaceous class.

Forest fragmentation is a serious phenomenon in the process of expansion of the agropastoral frontier in Brazil as it causes the isolation of different sized forest stretches among disturbed areas, leaving the periphery of fragments more exposed to insolation and modification of the wind regime (Silva et al., 2012). These changes were analyzed in the arboreal class since the expansion of livestock production was mainly due to the emergence of grasses with high adaptability to the climate and low-fertility soil (Lima \& Gama, 2018).

The species Brachiaria decumbes, is found in high frequency in the study area because it is perfectly adapted to the meager environmental conditions and provides high productivity, and thus is becoming the main plant introduced into pasture areas (Sá Souza et al., 2018). This study demonstrates that the edges of forest fragments represent suitable areas for the development of herbaceous species, which successfully inhabit this ecotonal environment (Muller et al., 2009).

\subsection{Transitions in the campo rupestre}

The high potential for natural regeneration of shrub species of the campo rupestre in areas of pasture (Viani et al., 2010) explains the $77 \%$ probability of shrub vegetation remaining from 1979 to 2015 (Table 3).

The large pastures and agricultural areas presently found in the campo rupestre are evidence of great environmental impacts (Fernandes et al., 2016), however, the natural restoration of campo rupestre can occur in pasture areas 
when they are abandoned due to low productivity (Silva et al., 2017). According to Luz et al. (2018), the natural restoration of vegetation occurs more easily in anthropized environments when the areas possess high potential for regeneration. However, the presence of exposed soil in many of the abandoned pasture areas of the study area indicates that the capacity for natural regeneration has been lost.

Pasture generally reduces the carbon and nitrogen concentration of the soil, since these elements are very vulnerable to cultivation because they are concentrated in the topsoil (Cavagnaro et al., 2016), and thus regeneration capacity is easily lost. However, some authors such as Silva et al. (2019) have reported that pasture establishment can not only recover soil carbon content but, in some cases, it can increase it.

The changes that occurred with the herbaceous class were represented by a $63 \%$ probability of persistence and $20 \%$ and $17 \%$ probability of conversion to arboreal and shrubby classes, respectively. The probability of persistence for this class is associated with the continuous use of areas for grazing.

Exotic species of the genus Brachiaria introduced for foraging were responsible for maintaining the exotic herbaceous class. In abandoned pastures these species indicated a potential for interference in regeneration and possess characteristics that favor the low growth of native herbaceous plants in open areas, such as tolerance for nutrient poor soils and vegetative propagation, resulting in greater competitive ability and, consequently, biomass accumulation (Calil et al., 2016).

The occurrence of abandoned pastures may also favor the conversion of $17 \%$ of the herbaceous area to shrub as represented in Table 3. Native herbaceous vegetation acts in the reconstitution of the original shrub vegetation by helping to protect the land from erosion; maintaining the necessary temperature, luminosity and humidity; and facilitating the attraction of animals by restoring animal-plant interactions. (Reis et al., 2003).

Changes in the composition of vegetation of natural ecosystems associated with pasture and agricultural practices can have serious consequences, not only with regard to biodiversity, but also regarding the deterioration of the soil and the consequent variation in the local climate (Longo et al., 2000). Lack of management and an increase in abandoned pastures can lead to total degradation of the soil and other natural resources, with irrecoverable losses for all of society (Peron \& Evangelista, 2004). Thus, in order to analyze transitions among vegetation classes of the Cerrado and Atlantic Forest biomes, this study constitutes a relevant resource for predicting damage to the environment, and can serve to facilitate local ecosystem maintenance.

\section{ACKNOWLEDGMENT}

The authors thank two anonymous reviewers for their comments that improved the manuscript, $\mathrm{CNPq}$ and Fapemig for research grants. This study was partially financed by the Coordenação de Aperfeiçoamento de Pessoal de Nível Superior - Brasil (CAPES) - Finance Code 001.

\section{SUBMISSION STATUS}

Received: 12 Jul. 2019

Accepted: 23 Nov. 2020

Associate editor: Marcel Carvalho Abreu (1)

\section{CORRESPONDENCE TO}

\section{Natália Viveiros Salomão}

Universidade Federal dos Vales do Jequitinhonha e Mucuri, R. Cruzeiro, 1, CEP 39803-371, Diamantina, MG, Brasil

e-mail: viveiros.natalia@yahoo.com.br

\section{REFERENCES}

Bolf EL, Pereira RS, Madruga PRA, Fonseca EL. Avaliação da classificação digital de povoamentos florestais em imagens de satélite através de índices de acurácia. Árvore 2004, 28(1): 85-90.

Calil FN, Lima NL, Silva RT, Moraes MDA, Barbosa PVL, Lima PAF, Brandão DC, Silva-neto CM, Carvalho HCS, Nascimento AR. Biomass and nutrition stock of grassland and accumulated litter in a silvopastoral system with Cerrado species. African Journal of Agricultural Research 2016, Vol. 11(38): 3701-3709.

Cavagnaro TR, Cunningham SC, Fitzpatrick S. Pastures to woodlands: changes in soil microbial communities and carbon following reforestation. Applied Soil Ecology 2016, 107: 24-32.

Coelho HR, Montenegro SMGL, Almeida CN, Lima VER, Neto AR, Moura GSS. Dinâmica do uso e ocupação do solo em uma bacia hidrográfica do semiárido brasileiro. Revista Brasileira de Engenharia Agrícola e Ambiental 2014, 18(1): 64-72.

Costa A, Galvão A, Da Silva LG. Mata Atlântica Brasileira: Análise do efeito de borda em fragmentos florestais remanescentes de um hotspot para conservação da biodiversidade. Geomae 2019, 10(1): 112-123.

Cunha AM, Lani JL, Amaral EF, Rezende SB, Ribeiro LS. Mosaico digital de aerofotos não-convencionais na avaliação de recursos naturais: Estudo de caso. Revista Brasileira de Engenharia Agrícola e Ambiental 2006, 10(1): 182-187.

Dantas MS, Almeira NV, Medeiros IS, Silva MD. Diagnóstico da vegetação remanescente de Mata Atlântica e ecossistemas associados em espaços urbanos. Journal of Environmental Analysis and Progress 2017, 2(1): 87-97.

Espírito-santo FDB, Shimabukuro YE. Validação do mapeamento de uma área de Floresta Tropical com o uso de imagens de videografia aérea e dados de levantamento de campo. Árvore 2005, 29(2): 227-239.

Fernandes GW. Ecology and Conservation of Mountaintop Grasslands in Brazil. Switzerland: Springer; 2016.

Fernandes MM, Fernandes MRM. Análise espacial da fragmentação florestal da bacia do rio Ubá. - RJ. Ciência Florestal 2017, (27) 4: 1429-1439. 
Filho AAR, Moura AC. Special Zones of Social Interest Using Multicriteria Analysis. Mercator 2016, 15 (3): 67-84.

Garcia AS, Ballester MVR. Land cover and land use changes in a Brazilian Cerrado landscape: drivers, processes, and patterns. Journal of Land Use Science 2016, 11(5): 538-559.

Gotelli N J. Ecologia., 4nd. edn. São Paulo: Planta; 2009

Hua AK. Application of ca-markov model and land use/land cover changes in Malacca river watershed, Malaysia. Applied Ecology and Environmental Research 2017, 15(4):605-622.

Köppen W, Geiger R. Klimate der Erde. Gotha 1928: Verlag. (Wallmap $150 \mathrm{~cm} \times 200 \mathrm{~cm}$ ).

Lima MCD, Gama DC. O sistema de integração lavoura-pecuáriafloresta no Brasil: conceitos, desafios e novas perspectivas. Agroforestalis News 2018, 3(1): 31-51.

Longo RM, Espindola CR. C-orgânico, N-total e substâncias húmicas sob influência da introdução de pastagens (Brachiaria sp.) em áreas de Cerrado e Floresta Amazônica. Revista Brasileira de Ciência do Solo 2000, 24(4): 723-729.

Luz GR, Mota GS, Spadeto C, Tolentino GC, Fernandes GW, Nunes YRF. Regenerative potential of the soil seed bank along an elevation gradient of rupestrian grassland in Southeastern Brazil. Botany 2018, 96(5): 281-298.

Mao J, Nierop KGJ, Dekker SC, Dekker LW, Chen B. Understanding the mechanisms of soil water repellency from nanoscale to ecosystem scale: a review. Journal of Soils and Sediments 2016, 19: 171-185.

Maurano LEP, Escada MIS, Renno CD. Padrões espaciais de desmatamento e a estimativa da exatidão dos mapas do PRODES para Amazônia Legal Brasileira. Ciência Florestal 2019, 29 (4):1763-1775.

Messias KG. Análise de uso do solo utilizando diferentes técnicas e imagens de média e alta resolução espacial. Revista de Geografia 2012, 2(1): 1-9.

Mingoti C, Spadotto CA, Moraes DAC. Suscetibilidade à contaminação da água subterrânea em função de propriedades dos solos no Cerrado brasileiro. Pesquisa Agropecuária Brasileira 2016, 51(9): 1252-1260.

Muller A, Bataghin FA, Santos SC. Efeito de borda sobre a comunidade arbórea em um fragmento de Floresta Ombrófila mista, Rio Grande do Sul, Brasil. Perspectiva, 2009, 34(125): 29-39.

Nappo ME, Griffith JJ, Martins SV, Júnior PM, Souza AL, OliveiraFilho AT. Dinâmica da estrutura fitossociológica da regeneração natural em sub-bosque de Mimosa Scabrella bentham em área minerada, em Poços de Caldas, MG. Árvore 2004, 28(6): 811-829.

Nóbrega LRB, Guzha AC, Torres GN, Kovacs K, Lamparter G, Amorim RSS, Couto E, Gerold G. Effects of conversion of native cerrado vegetation to pasture on soil hydro-physical properties, evapotranspiration and streamflow on the Amazonian agricultural frontier. PLoS One 2017, 12(6): 1-22.

Panizza AC, Fonseca FP. Técnicas de interpretação visual de imagens. GeoUSP 2011, 30: 30-43.

Pendril F, Persson UM, Godar J, Kastner T. Deforestation displaced: trade in forest-risk commodities and the prospects for a global forest transition. Environmental Research Letters 2019, 14: 1-20.
Peron AJ, Evangelista AR. Pasture degradation in savanna's regions. Ciência e Agrotecnologia 2004, 28(3): 655-661.

Pleniz LP. O desmatamento no bioma Amazônia brasileira e sua (possível) relação com a expansão dos cultivos de commodities agrícolas. Estudos Sociedade e Agricultura 2016, 24(1): 243-262.

Reis A, Bechara FC, Espíndola MB, Vieira NK, Souza LL. Restauração de áreas degradadas: a nucleação como base para incrementar os processos sucessionais. Natureza \& Conservação 2003, 1(1): 28-36.

Resende FC, Cardozo FS, Pereira G. Análise ambiental da ocorrência das queimadas na porção nordeste do Cerrado. Revista do departamento de Geografia 2017, 34: 31-42.

Romero-Ruiz MH, Flantua SGA, Tansey K, Berrio JC. Landscape transformation in savannas of northern South America: Land use/ cover changes since 1987 in the Llanos Orientales of Colombia. Applied Geography 2012, 32(2): 766- 776.

Rudorff CM, Rizzi R, Rudorff BFT, Sugawara LM, Vieira CAO. Superfícies de resposta espectro-temporal de imagens do sensor MODIS para classificação de área de soja no estado do Rio Grande do Sul. Ciência Rural 2007, 37(1): 118-125.

Ruhoff A, Fantin-cruz I, Collischonn W. Modelos de simulação dinâmica do desmatamento da Amazônia. Caminhos da Geografia 2010, Uberlândia 11(36): 258-268.

Sá Souza M, Jardim AMRF, Júnior GNA, Silva JRI, Leite GNA, Teixeira VI, Silva TGF. Ciclagem de nutrientes em ecossistemas de pastagens tropicais. Pubvet 2018, (12)5: 1-9.

Salomão NV, Machado ELM, Pereira RS, Fernandes GW, Gonzaga APD, Mucida PD, Silva LS. Structural analysis of a fragmented area in Minas Gerais State, Brazil. Anais da Academia Brasileira de Ciências 2018, 90(4): 3353-3361.

Salomão NV, Silva MDD, Machado ELM. Dynamics of vegetation structure in a fragmented landscape in Minas Gerais, Brazil. Brazilian Journal of Biology 2019, 79(4):678-685.

Santos GL, Delgado RC, Pereira MG, Torres JRL. Evaluation of natural regeneration and recovery of environmental services in a watershed in the Cerrado-Brazil. Environment Development and Sustainability 2019, 1-14.

Silva CR, Silva V, Junior JA, Carvalho HP. Radiação solar estimada com base na temperatura do ar para três regiões de Minas Gerais. Revista Brasileira de Engenharia Agrícola e Ambiental 2012, 16(3): 281-288.

Silva MRSS, Castro AP, Krüger RH, Bustamante M. Soil bacterial communities in the Brazilian Cerrado: Response to vegetation type and management. Acta Oecologica 2019, 100.

Silva RO, Barioni LG, Hall JAJ, Moretti AC, Veloso RF, Alexander P, Crespolini M, Moran D. Sustainable intensification of Brazilian livestock production through optimized pasture restoration. Agricultural Systems 2017, 153: 201-211.

Staal A, Nes EHV, Hantson S, Holmgren M, Dekker SC, Pueyo S, Xu C, Scheffer M. Resilience of tropical tree cover: The roles of climate, fire, and herbivory. Global Change Biology 2018, 24:5096-5109.

Viani RAG, Durigan G, Melo ACG. A regeneração natural sob plantações florestais: desertos verdes ou redutos de biodiversidade? Ciência Florestal 2010, 20(3): 533-552. 